\title{
Kajian Pemberdayaan Masyarakat Dengan Teknologi Tepat Guna (Produksi Olahan Bambu)
}

Conference Paper · September 2012

CITATIONS

0

2 authors, including:

M. Adhi Prasnowo

Universitas Maarif Hasyim Latif, Indonesia, Sidoarjo

4 PUBLICATIONS 0 CITATIONS

SEE PROFILE
READS

16

Some of the authors of this publication are also working on these related projects:

Project

Prepare to ASIA International Multidisciplinary Conference (AIMC) 2017, UTM Johor Bahru, Malaysia. View project

All content following this page was uploaded by M. Adhi Prasnowo on 09 March 2017. 


\title{
Kajian Pemberdayaan Masyarakat Dengan Teknologi Tepat Guna (Produksi Olahan Bambu)
}

\author{
M Adhi Prasnowo ${ }^{1,}{ }^{K}$ hoirul Hidayat ${ }^{2}$ \\ ${ }^{1}$ UD. Adi Teknik Ds. Terungkulon RT 01 RW 02 Krian Sidoarjo \\ ${ }^{2}$ Program Studi Teknik Industri Universitas Ma Chung Malang \\ Email: prasnowoadhi@yahoo.co.id
}

\begin{abstract}
Abstrak
Pulau madura merupakan salah satu dari ribuan pulau yang ada di Indonesia dikenal sebagai lumbung penghasil sektor kelautan dan produksi garam. Setelah dibangunnya jembatan Suramadu, pulau madura diharapkan mempunyai daya saing di segala sektor perekonomian dengan lebih mudahnya akses transportasi. Untuk mendukung hal tersebut perlu adanya sektor penunjang kegiatan dan kemampuan sumber daya manusianya. Potensi yang besar dari hasil kekayaan alam pulau madura merupakan modal besar yang dimiliki pulau ini. Salah satunya adalah kekayaan alam berupa tanaman bambu. Sesuai dengan strategi nasional kementrian lingkungan hidup yang berusaha untuk memanfaatkan potensi tanaman bambu baik dari sisi ekonomis dan sisi ekologis bambu. Dalam upaya pemanfaatan tanaman bambu agar memiliki nilai ekonomi yang lebih, dalam hal ini pemanfaatan teknologi tepat guna harus juga diperhatikan agar hasil dari produksi olahan bambu memiliki standar dan kualitas yang mampu bersaing di pasar lokal maupun ekspor. Konsep orang tua asuh adalah bentuk konsep pemberdayaan sebagai langkah pertama dalam meningkatkan perekonomian masyarakat madura.

Kata kunci: Pemberdayaan masyarakat, teknologi tepat guna, olahan bambu

Abstract

MaduraIslandis oneof thethousands ofislands inIndonesiaknownas thegranaryproducer ofthe maritime sectorand the production ofsalt. Afterthe construction ofthe Suramadu bridge, Maduraislandis expected tohave acompetitive edgein allsectors ofthe economywith moreeasyaccess to transport. To supporttheneed forthe sectorto support activitiesandhumanresource capabilities. The enormous potential ofthe natural wealth ofthe Maduraisland is alarge capitalownedisland.One is thenaturalform ofbamboo plants. In accordancewith the national strategyof the environmentministrythat seeksto harnessthe potential ofbamboo plantsboth from theeconomicalandtheecologicalbamboo. In an effort tousebamboo plantsthathaveeconomicvalue, in this case theuse of appropriate technologyshouldalso be notedthat the resultsof the production ofprocessedbamboohas a standardand quality thatcan competein thelocal andexportmarkets. The concept offoster parentsis a form ofthe concept ofempowermentas a first stepin improvingtheeconomyof Madura.
\end{abstract}

Keywords: Community development, appropriate technology, processed bamboo

\section{PENDAHULUAN}

Pulau madura merupakan salah satu dari ribuan pulau yang ada di Indonesia dikenal sebagai lumbung penghasil sektor kelautan dan produksi garam. Setelah dibangunnya jembatan penghubung pulau madura dengan pulau jawa, pulau madura diharapkan mempunyai daya saing di segala sektor perekonomian dengan lebih mudahnya akses transportasi. Untuk mendukung hal tersebut perlu adanya sektor penunjang kegiatan dan kemampuan sumber daya manusianya. Potensi yang besar dari hasil kekayaan alam pulau madura merupakan modal besar yang dimiliki pulau ini. Salah satunya adalah kekayaan alam berupa tanaman bambu. Sesuai dengan strategi nasional kementrian lingkungan hidup yang berusaha untuk memanfaatkan potensi tanaman bambu baik dari sisi ekonomis dan sisi ekologis bambu. Dalam makalah ini pembahasan difokuskan dalam sisi ekonomis pemanfaatan bambu tetapi dengan diketahuinya nilai tambah secara ekonomi dari tanaman bambu tidak menutup kemungkinan masyarakat dan pemerintah setempat akan berupaya untuk tetap melakukan pelestarian tanaman bambu sehingga secara sisi ekologis strategi nasional akan tetap tercapai.

Daya dukung pulau madura sebagai pulau yang akan berkembang masih sangat besar hal ini dapat dilihat masih banyaknya lahan perkebunan dan pekarangan masyarakat yang masih memiliki jumlah tanaman bambu sebagai bahan baku untuk olahan bambu. Sehingga potensi tanaman bambu selayaknya sudah menjadi perhatian khusus bagi pihak-pihak terkait untuk dapat meningkatkan taraf ekonomi masyarakat. 


\section{METODE}

Dalam upaya pemanfaatan tanaman bambu agar memiliki nilai ekonomi yang lebih, dalam hal ini pemanfaatan teknologi harus juga diperhatikan agar hasil dari produksi olahan bambu memiliki standar dan kualitas yang mampu bersaing di pasar lokal maupun ekspor. Dalam upaya pengolahan bambu yang berbasis industri peralatan pendukung yang diaplikasikan dalam olahan tusuk sate, sumpit dan tusuk gigi, antara lain :

a. Mesin potong bambu

Mesin potong tersebut berfungsi untuk memotong bambu sesuai dengan ukuran panjang tusuk sate,sumpit dan tusuk gigi yang diingikan, panjang tusuk sate yang dijual di pasaran antara $20-30 \mathrm{~cm}$. Sistem operasi mesin ini menggunakan pisau piringan, dan mengenai panjang ukuran pada mesin ini diberikan standar acuan sehingga mempermudah dalam pemotongan dan menghindarkan dari kesalahan ukuran. Mesin potong ini memiliki dimensi panjang, lebar dan tinggi 50 × 50 x $90 \mathrm{~cm}$.

b. Mesin penipis bambu

Mesin penipis bambu berfungsi untuk membuat bilah bambu tipis dengan ketebalan yang dapat diatur sesuai kebutuhan.

c. Mesin Cetak

Mesin cetak berfungsi sebagai mesin untuk membuat stik tusuk sate, sumpit dan tusuk gigi dengan hasil berupa lidi bambu bulat panjang berdiameter sesuai dengan permintaan dan diameter yang banyak dipasaran adalah 2,5-3 $\mathrm{mm}$. Sistem kerja mesin ini menggunakan sistem sodok, dengan menggunakan sliding yang dihubungkan dengan poros engkol (essentrik), dan terdapat pisau pencetak sesuai diameter yang diinginkan. Kapasitas mesin cetak perhari $200 \mathrm{~kg}$. Dimensi mesin cetak adalah 100 x 70 x $90 \mathrm{~cm}$. Atau dapat juga menggunakan sistim roll slicer.

d. Mesin Polish

Mesin polish atau penghalus berfungsi untuk menghaluskan permukaan stik dari serabut halus hasil cetakan, karena jika tidak dilakukan penghalusan kualitas tusuk sate,tusuk gigi dan sumpit akan jelek dan tidak dapat diproses pada mesin peruncing. Mesin polish mempunyai kapasitas $200 \mathrm{~kg}$ perhari dan dapat dinaikkan dengan menambah kabin polishnya. Sistem kerja mesin ini menggunakan poros engkol. Dimensi mesin polish adalah $120 \mathrm{x}$ $60 \times 50 \mathrm{~cm}$.

\section{e. Mesin Peruncing}

Mesin peruncing digunakan untuk membentuk runcingan pada salah satu ujung tusuk sate, tusuk gigi dan sumpit. Adapun sistem kerja mesin ini adalah semi otomatis sehingga operator hanya meletakkan dan kemudian mengambil saja. Kapasitas perhari dari mesin peruncing ini adalah $200 \mathrm{~kg}$ per hari. Dimensi mesin peruncing adalah $110 \times 60 \times 100 \mathrm{~cm}$.

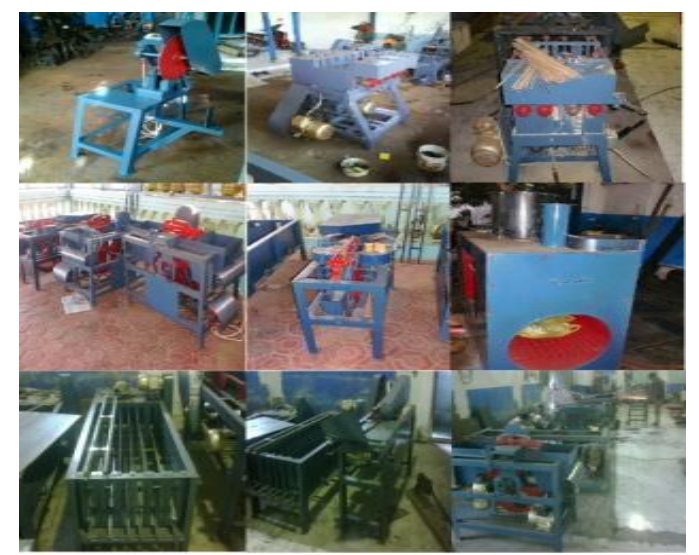

Gambar 1. Peralatan untuk produksi olahan bambu

Untuk beberapa peralatan pendukung diatas tidak hanya dapat digunakan untuk produksi olahan bambu berupa tusuk sate, tusuk gigi dan sumpit saja melainkan juga dapat digunakan untuk memproduksi besek ikan, gedhek, dan kerajinan bambu Sehingga dapat menjadi alternatif untuk kegiatan pemberdayaan jenis olahan yang lain. 


\section{Sniro \\ Seminar Nasional Industrialisasi Madura \& Call for Paper 2012}

\section{PEMBAHASAN}

Pasar yang masih terbuka untuk kebutuhan hasil olahan bambu tersebut membuat potensi usaha pemberdayaan masyarakat ini dapat berjalan secara berkelanjutan, untuk memasok kebutuhan pasar lokal sampai sekarang ini beberapa sentra produsen olahan bambu masih belum bisa mencukupi. Belum lagi masih terbukanya pintu ekspor ke beberapa negara antara lain : Cina, jepang dan beberapa negara timur tengah.

Konsep pelaksanaan penerapan teknologi tepat guna produksi olahan bambu adalah dengan diharapkannya pihak-pihak terkait untuk dapat berpartisipasi, baik dari pemerintah setempat ataupun instansi-instansi swasta untuk menjadi pembina ataupun orang tua asuh bagi masyarakat. Oleh karenanya perlu dibentuk teknis pemberdayaan agar tujuan dari pemberdayaan masyarakat ini tercapai. Teknis pemberdayaan pengolahan bambu dapat dibentuk dengan melakukan pembinaan-pembinaan kepada masyarakat meliputi beberapa hal, antara lain :

a. Pembinaan masyarakat tentang pengembangan tanaman bambu, sebagai bahan baku utama kelangsungan hidup tanaman bambu harus selalu dilestarikan sehingga kelangsungan usaha pemberdayaan masyarakat akan terus berjalan.

b. Pembinaan teknologi proses industri/kerajinan dan pemasaran

Peningkatan ketrampilan teknis dalam teknologi proses seperti mengemas dan menyeleksi hasil produksi serta peralatan yang diperlukan untuk mempertahankan kualitas hingga cara prosesing akhir produk untuk meningkatkan nilai tambah serta kemampuan pemasaran. Untuk melaksanakan pembinaan dengan sarana yang tersedia di wilayah agar lebih optimal, maka kerjasama dengan Jajaran Departemen Perindustrian dan Perdagangan setempat harus dilakukan. Sinergi kegiatan hanya dapat dicapai dengan koordinasi perencanaan dan pembagian tugas yang jelas.

c. Pembinaan pengembangan usaha bersama

Kelompok kegiatan yang menyangkut peningkatan kemam puan mengelola usaha dan melaksanakan kemitraan dengan pedagang, eksportir maupun industri pengelohan pangan dilaksanakan melalui pembinaan Kelompok Usaha Bersama Industri/kerajinan rakyat (KUBA) dan Koperasi Perajin Bambu, pembentukan Forum Komunikasi (FORKA) Perajin Bambu, pelaksanaan temu-temu usaha, pelatihan kewirausahaan dan promosi produk.

\section{KESIMPULAN}

Madura sebagai satu wilayah yang banyak menyediakan sumber daya alam tanaman bambu sebagai upaya untuk meningkatkan pendapatan masyarakatnya, konsep orang tua asuh adalah bentuk konsep pemberdayaan sebagai langkah pertama. Diharapkan agar intansi-intansi baik dari pemerintah atupun swasta dapat memberikan partisipasi.

Faktor-faktor yang harus terus diupayakan agar kelangsungan usaha pemberdayaan masyarakat terus berjalan adalah dengan memperhatikan hal-hal berikut :

a. Ketersediaan bahan baku tanaman bambu, dalam hal ini upaya konservasi dan pelestarian tanaman bambu harus dilakukan dengan memanfaatkan lahan tidur, mengetahui masa panen tanaman bambu dan tidak mengganti tanaman bambu dengan tanaman yang lain.

b. Kebijakan pemerintah tentang penataan tata ruang wilayah agar lahan bambu yang tersedia.

c. Melakukan pengawasan dan pembinaan yang intensif kepada masyarakat agar tujuan pemberdayaan dapat tercapai.

Farrelly, David (1984). The Book of Bamboo. Sierra

\section{DAFTAR PUSTAKA}

Strategi Nasional dan Rancang tindak pelestarian bambu dan pemanfaatannya secara berkelanjutan di Indonesia (1998), Kementrian Lingkungan Hidup republik Indonesia.

Dhandyta,(2012) Rancangan Sentra Pengembangan Komoditas Unggulan (SPAKU) Kerajinan Bambu.

Hendarto, K.A. (2005). Proyek Kehutanan Sosial dan Penganggaran Berwawasan Gender:Suatu Ulasan Teoritis.

Mardi Yatmo Hutomo, (2000). Pemberdayaan Masyarakat dalam Bidang Ekonomi:Tinjauan Teoritik dan Implementasi

www.adi-teknik.blogspot.com 